\title{
Analisis Kinerja Fuzzy C-Means (FCM) dan Fuzzy Subtractive (FS) dalam Clustering Data Alumni STMIK STIKOM Indonesia
}

\author{
I Kadek Dwi Gandika Supartha*, Adi Panca Saputra Iskandar** \\ STMIK STIKOM Indonesia \\ *gandika.supartha@stiki-indonesia.ac.id, ${ }^{* *}$ adipancaiskandar@gmail.com
}

\begin{abstract}
In this study, clustering data on STMIK STIKOM Indonesia alumni using the Fuzzy C-Means and Fuzzy Subtractive methods. The method used to test the validity of the cluster is the Modified Partition Coefficient (MPC) and Classification Entropy $(C E)$ index. Clustering is carried out with the aim of finding hidden patterns or information from a fairly large data set, considering that so far the alumni data at STMIK STIKOM Indonesia have not undergone a data mining process. The results of measuring cluster validity using the Modified Partition Coefficient (MPC) and Classification Entropy (CE) index, the Fuzzy C-Means Clustering algorithm has a higher level of validity than the Fuzzy Subtractive Clustering algorithm so it can be said that the Fuzzy C-Means algorithm performs the cluster process better than with the Fuzzy Subtractive method in clustering alumni data. The number of clusters that have the best fitness value / the most optimal number of clusters based on the CE and MPC validity index is 5 clusters. The cluster that has the best characteristics is the 1st cluster which has 514 members $(36,82 \%$ of the total alumni). With the characteristics of having an average GPA of 3,3617, the average study period is 7,8102 semesters and an average TA work period of 4,9596 months.
\end{abstract}

Keyword: cluster, alumni, Fuzz C-Means, Fuzzy Subtractive

\section{Introduction}

Tingginya tingkat persaingan tenaga kerja saat ini menuntut kualitas individu yang semakin meningkat. Hal ini memiliki hubungan yang sangat erat dengan kualitas lulusan perguruan tinggi, dengan demikian kualitas suatu perguruan tinggi pun perlu ditinjau kembali untuk ditingkatkan. Selain masukan yang baik dari tracer study sebuah perguruan tinggi, kualitas sebuah perguruan tinggi dapat dilihat dari sebaran lulusan di dunia kerja. Lulusan pada perguruan tinggi disebut sebagai alumni atau merupakan mahasiswa/i yang telah mengikuti atau tamat dari perguruan tinggi.

STMIK STIKOM Indonesia (STIKI Indonesia) merupakan salah satu perguruan tinggi yang berlokasi di Denpasar Bali, berdiri sejak tahun 2008 dan sampai saat ini memiliki alumni kurang lebih 2000 orang. Mahasiswa yang telah menjadi alumni ditampung dalam sebuah organisasi dengan nama Ikatan Alumni STIKI Indonesia (IKA-STIKI). IKA-STIKI memiliki tugas untuk mengelola data alumni dan menjalin komunikasi dengan alumni. Secara berkala pendataan alumni dilakukan diantaranya dengan cara tracer study, informasi yang didapatkan yaitu tempat bekerja, bidang kerja, lama bekerja, kesesuaian bidang kerja, jumlah alumni, IPK (Indeks Prestasi Komulatif), lama study dan lama pengerjaan tugas akhir. Data alumni yang sudah terkumpul cukup banyak kurang begitu dimaksimalkan dan kurang diolah menjadi informasi yang lebih berguna, untuk mendapatkan informasi tersembunyi dari kumpulan data alumni yang sangat banyak dapat menggunakan teknologi data mining, sehingga hasil dari data mining bisa dimanfaatkan untuk membantu dalam mengambil kebijakan di perguruan tinggi seperti perubahan silabus ataupun perbaikan kurikulum [1][2].

Data mining merupakan proses pencarian pola-pola yang menarik dan tersembunyi dari suatu kumpulan data yang berukuran besar yang tersimpan dalam suatu basis data [3]. Salah satu metode yang diterapkan dalam data mining adalah clustering. Menurut [4] teknik clustering digunakan untuk mengelompokkan objek-objek yang memiliki kemiripan dalam kelas atau segmen yang sama. Pada penelitian ini metode yang akan digunakan dalam melakukan cluster data alumni adalah metode fuzzy clustering yaitu dengan algoritma Fuzzy C-Means Clustering (FCM) dan Fuzzy Subtractive Clustering (FS). Algoritma Fuzzy C-Means Clustering merupakan algoritma supervised clustering (jumlah cluster ditentukan). FCM memiliki tingkat akurasi yang tinggi dan waktu komputasi yang cepat [5], sedangkan Fuzzy Subtractive Clustering (FS) termasuk algoritma unsupervised clustering dimana jumlah cluster tidak ditentukan. Hasil pengelompokan data 
menggunakan kedua algoritma tersebut nantinya dapat dibandingkan. Atribut yang akan digunakan dalam melakukan clustering yaitu: Indeks Prestasi Komulatif (IPK), lama study dan lama pengerjaan tugas akhir. Validitas partisi fuzzy akan diterapkan dalam proses clustering, metode yang akan digunakan untuk menguji validitas cluster pada penelitian ini adalah indeks Modified Partition Coefficient (MPC) dan Classification Entropy (CE).

Pemanfaatan data alumni dengan menggunakan teknik data mining, dimulai dari selection data pada system existing yang akan melewati proses Extract-Transform-Load (ETL) menjadi sebuah data yang siap untuk di mining, kemudian proses mining dilakukan dengan metode FCM dan FS. Hasil clustering kemudian dianalisa untuk mentukan karakteristik alumni. Data yang telah dianalisi disajikan pada stakeholder perguruan tinggi sehingga perguruan tinggi dapat mengambil keputusan dan langkah langkah untuk mengantisipasi halhal yang tidak harus terjadi. Dengan harapan perguruan tinggi STMIK STIKOM Indonesia dapat terus mengukur kualitas lulusan serta kualitas perguruan tinggi dari hasil pemanfaatan data alumni. Hasil penelitian ini diharapkan dapat membantu STMIK STIKOM Indonesia dalam melakukan pengambilan keputusan seperti peninjauan kurikulum ataupun perbaikan silabus dengan tujuan untuk meningkatkan kualitas lulusan.

\section{Research Method}

Objek penelitian adalah data alumni di STMIK STIKOM Indonesia, yang merupakan salah satu sekolah tinggi di bidang ilmu komputer di Bali. STMIK STIKOM Indonesia berdiri sejak tahun 2008 dengan mengelola dua (2) program studi, yaitu Teknik Informatika dan Sistem Komputer dimana keduanya merupakan pendidikan jenjang Sarjana (S1).

Tahapan penelitian clustering data alumni dapat dilihat pada Gambar 1 di bawah ini

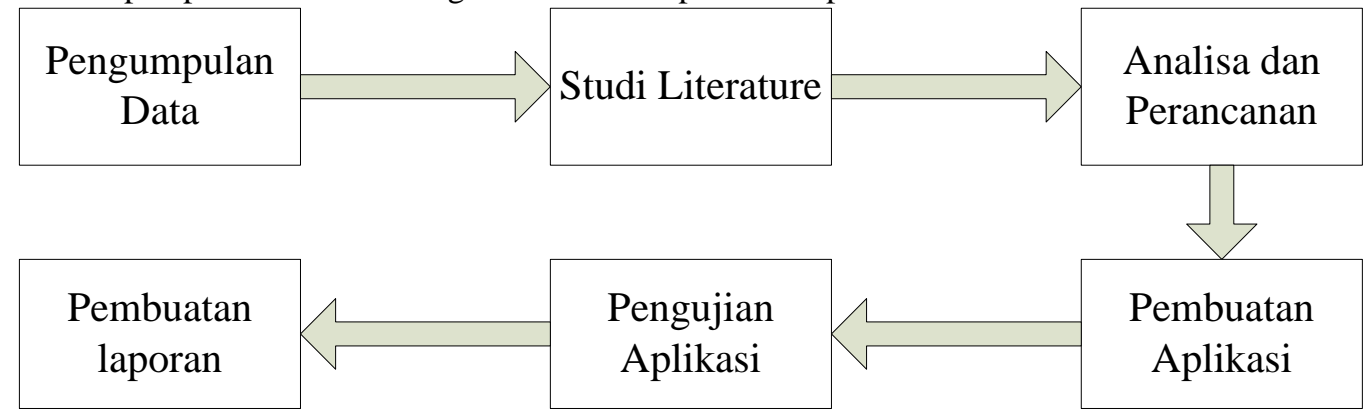

Gambar 1. Tahapan Penelitian

\subsection{Pengumpulan Data}

Teknik pengumpulan data yang digunakan yaitu observasi dan wawancara. Observasi dilakukan dengan cara menghubungi pihak yang menyediakan data alumni yang akan digunakan dalam penelitian dalam hal ini yaitu STMIK STIKOM Indonesia (STIKI Indonesia) yaitu dibagian alumni. Wawancara dilakukan secara langsung kepada bagian kemahasiswaan dan alumni. Observasi dan wawancara dilakukan untuk mengetahui pengumpulan dan cara pemrosesan data alumni yang selama ini dilakukan di STMIK STIKOM Indonesia. Jumlah data alumni yang digunakan dalam penelitian ini adalah sebanyak 1396 alumni

\subsection{Studi Literature}

Studi Literature dilakukan dengan membaca buku-buku literatur yang berkaitan dengan materi yang dipergunakan dalam penelitian. Materi yang digunakan dalam penelitian ini yaitu:

\subsubsection{Data Mining}

Data mining merupakan proses pencarian pola-pola yang menarik dan tersembunyi (hidden pattern) dari suatu kumpulan data yang berukuran besar yang tersimpan dalam suatu basis data, data warehouse, atau tempat penyimpanan data lainnya [6]. Proses data mining dapat dilihat pada Gambar 2 dibawah ini 


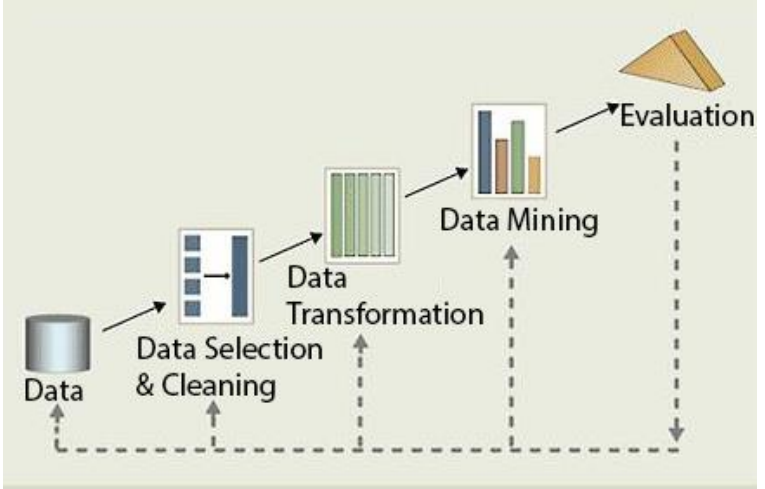

Gambar 2 Proses Data Mining

\subsubsection{Clustering}

Pengelompokan (clustering) merupakan teknik yang sudah cukup dikenal dan banyak digunakan untuk mengelompokkan data/objek ke dalam kelompok data (cluster) sehingga setiap cluster memiliki data yang mirip dan berbeda dengan data yang berada dalam cluster lain. Dalam conceptual clustering, objek dikelompokkan berdasarkan kecocokannya menurut konsep deskriptif. Gambar 3 memperlihatkan contoh proses clustering.

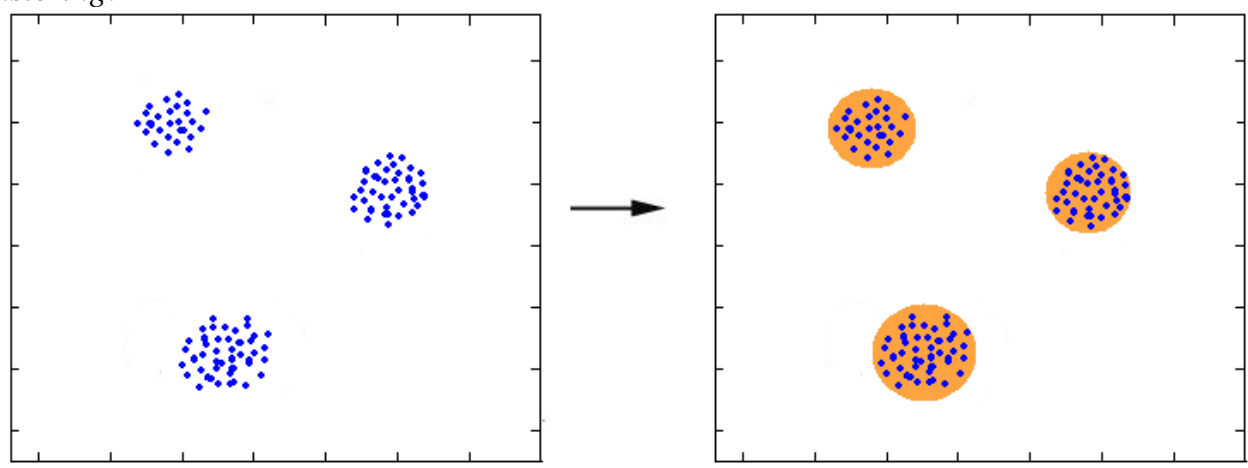

Gambar 3 Proses Clustering

\subsubsection{Fuzzy C-Means (FCM) dan Fuzzy Subtractive (FS)}

Metode Fuzzy C-Means Clustering pertama kali dikenalkan oleh Jim Bezdek pada tahun 1981 [4]. Fuzzy C-Means adalah salah satu teknik pengelompokkan data yang mana keberadaan tiap titik data dalam suatu kelompok (cluster) ditentukan oleh derajat keanggotan. Metode Fuzzy C-Means termasuk metode supervised clustering dimana jumlah pusat cluster ditentukan di dalam proses clustering. Algoritma dari fuzzy $c$-means adalah sebagai berikut:

1. Input data yang akan dikelompokkan

2. Tentukan jumlah cluster (c), pangkat untuk matriks partisi (w), maksimum iterasi (MaxIter), error terkecil yang diharapkan $(\xi)$, fungsi objektif awal $(P o=0)$, dan iterasi awal $(t=1)$

3. Bangkitkan bilangan random $\eta_{i k}, \mathrm{i}=1,2, \ldots n ; \mathrm{k}=1,2, \ldots c$

4. Hitung pusat cluster dengan persamaan:

$$
V_{k j}=\frac{\sum_{i=1}^{n}\left(\left(\mu_{i k}\right)^{w} \cdot X_{i j}\right)}{\sum_{i=1}^{n}\left(\mu_{i k}\right)^{w}}
$$

$V_{k j}$ adalah pusat $c l u s t e r$ ke- $k$ untuk atribut ke-j, $\eta_{i k}$ adalah derajat keanggotaan untuk data sampel ke-i pada cluster $k e-k, x_{i j}$ adalah data ke- $i$, atribut ke- $j$

5. Hitung fungsi objektif pada iterasi ke-t dengan persamaan

$$
P_{t}=\sum_{i=1}^{n} \sum_{k=1}^{c}\left(\left[\sum_{j=1}^{m}\left(X_{i j}-V_{k j}\right)^{2}\right]\left(\mu_{i k}\right)^{w}\right)
$$

$V_{k j}$ adalah pusat $c l u s t e r$ ke- $k$ untuk atribut ke-j, $\eta_{i k}$ adalah derajat keanggotaan, $x_{i j}$ adalah data ke- $i$, atribut ke-j, $P_{t}$ adalah fungsi objektif pada iterasi ke- $t$

6. Hitung perubahan matriks partisi menggunakan persamaan: 


$$
\mu_{i k}=\frac{\left[\sum_{j=1}^{m}\left(X_{i j}-V_{k j}\right)^{2}\right]^{\frac{-1}{w-1}}}{\sum_{k=1}^{c}\left[\sum_{j=1}^{m}\left(X_{i j}-V_{k j}\right)^{2}\right]^{\frac{-1}{w-1}}} .
$$

$V_{k j}$ adalah pusat $c l u s t e r$ ke- $k$ untuk atribut ke-j, $\eta_{i k}$ adalah derajat keanggotaan, $x_{i j}$ adalah data ke- $i$, atribut ke-j

7. Cek Kondisi berhenti: Jika : $\left(\left|P_{t}-P_{t-1}\right|<\varepsilon\right)$ atau ( $t>$ Maxlter) maka berhenti. Jika tidak: $t=t+1$, ulangi langkah ke-4

Dasar dari metode Fuzzy Subtractive Clustering adalah ukuran densitas (potensi) titik-titik data dalam suatu ruang (variabel). Konsep dasar dari metode Fuzzy Subtractive Clustering adalah menentukan daerahdaerah dalam suatu variabel yang memiliki densitas tinggi terhadap titik-titik di sekitarnya. Titik dengan jumlah tetangga terbanyak akan dipilih untuk menjadi pusat kelompok. Titik yang sudah dipilih menjadi pusat kelompok ini kemudian akan dikurangi densitasnya. Selanjutnya akan dipilih titik lain yang menjadi tetangga terbanyak untuk dijadikan pusat kelompok yang lain. densitas suatu titik dapat dihitung dengan persamaan:

$$
\mathrm{D}_{\mathrm{k}}=\sum_{j=1}^{n} \mathrm{e}^{\left(-\frac{\left\|\mathrm{x}_{\mathrm{k}}-\mathrm{x}_{\mathrm{i}}\right\|}{\left(\frac{\mathrm{r}_{\mathrm{a}}}{2}\right)^{2}}\right)}
$$

Dk= Densitas titik ke-k, $\mathrm{xk}=$ titik ke-k, ra = konstanta positif.

Misalkan xc1 adalah titik yang terpilih menjadi pusat kelompok dan Dc1 adalah ukuran densitasnya, selanjutnya densitas dari titik-titik di sekitarnya akan dikurangi dengan persamaan:

$$
D_{k}=D_{k}-D_{c 1} * \mathrm{e}^{\left(-\frac{\left\|\mathrm{x}_{\mathrm{k}}-\mathrm{x}_{\mathrm{c} 1}\right\|}{\left(\frac{\mathrm{r}_{\mathrm{b}}}{2}\right)^{2}}\right)} .
$$

Nilai rb menunjukkan suatu lingkungan yang mengakibatkan titik-titik berkurang ukuran densitasnya. Nilai rb diperoleh dari persamaan :

$$
r_{b}=\text { squashfactor } * r_{a}
$$

Biasanya squashfactor bernilai 1,5. Dengan demikian rb bernilai lebih besar dibandingkan ra.

\subsection{Analisa dan Perancangan}

Berdasarkan pengumpulan data yang telah didapatkan maka kebutuhan dari aplikasi clustering data alumni dengan Fuzzy C-Means dan Fuzzy Substractive yaitu user memerlukan sebuah aplikasi yang mampu melakukan clustering data alumni dengan metode Fuzzy C-Means dan Fuzzy Substractive serta dapat memberikan informasi yang dapat digunakan untuk melakukan analisa clustering.

Perancangan gambaran umum dari penelitian ini dapat dilihat pada Gambar 4 di bawah ini

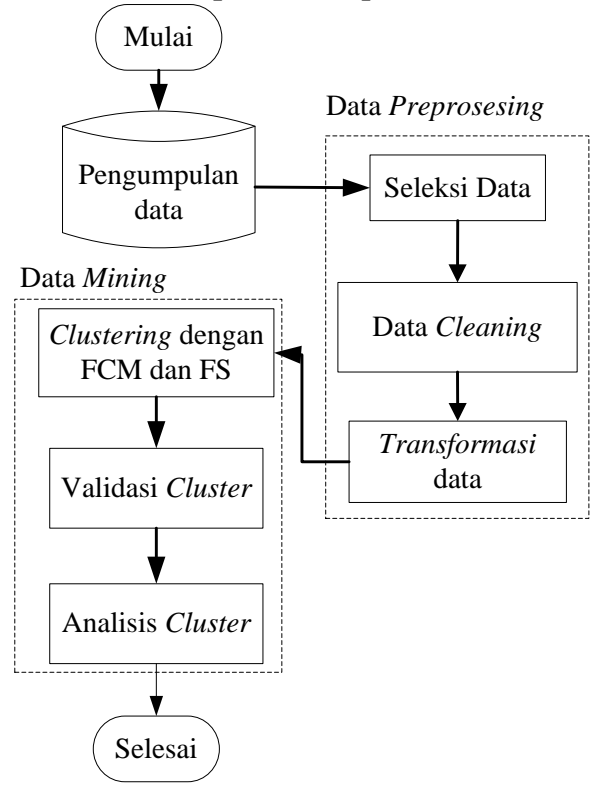

Gambar 4 Gambaran Umum Sistem

Berdasarkan Gambar 4 dapat dijelaskan bahwa gambaran umum penelitian secara garis besar dibagi menjadi 3 tahapan yaitu pengumpulan data, data preprosesing dan tahapan data mining.

\subsubsection{Pengumpulan Data}


Pada tahapan ini yang dilakukan yaitu mengumpulkan data yang akan digunakan dalam penelitian ini. Data tersebut berjenis data sekunder yaitu data alumni STIKI Indonesia. Atribut data alumni yang akan digunakan dalam penelitian ini yaitu :Indeks Prestasi Kumulatif (IPK), lama studi (dalam semester), lama pengerjaan tugas akhir (dalam bulan). Pemilihan atribut ini dilakukan karena tidak semua data alumni dapat digunakan dalam proses data mining misalkan seperti alamat dan nomor telpon.

\subsubsection{Data Preprosesing}

Dalam tahapan ini terdapat tiga langkah yaitu seleksi data, data cleaning dan transformasi data. Tujuan dari tahapan ini adalah untuk mengubah data mentah menjadi data yang berkualitas, seperti memperbaiki data yang incomplete (tidak lengkap), noisy (data berisi kesalahan nilai) dan data tidak konsisten. 1. Seleksi Data

Pada tahapan seleksi data yang akan dilakukan yaitu melakukan seleksi atribut yang akan digunakan. Tentunya tidak semua atribut dimasukkan dalam set data yang digunakan dalam proses data mining karena hanya yang berperan sebagai referensi identifikasi yang akan dipilih. Dari semua atribut yang disebutkan diatas maka yang digunakan dalam data mining yaitu atribut Indeks Prestasi Kumulatif (IPK), Lama masa studi (dalam semester), Lama pengerjaan Tugas Akhir (TA) dalam bulan. Tabel 1 menunjukkan data yang telah mengalami seleksi data.

Tabel 1 Seleksi Data

\begin{tabular}{|lllll|}
\hline NO & NIM & IPK & Lama Studi & Pengerjaan TA \\
\hline 1 & 08101011 & 2.99 & 10 & 3 \\
\hline 2 & 08101014 & 3.14 & 10 & 4 \\
\hline 3 & 08101018 & 3.46 & 10 & 10 \\
\hline 4 & 08101023 & 3.26 & 10 & 11 \\
\hline 5 & 08101024 & 2.59 & 10 & 11 \\
\hline 6 & 08101026 & 3.1 & 8 & 6 \\
\hline
\end{tabular}

\section{Data Cleaning}

Tujuan dari proses ini adalah untuk memastikan kualitas data yang telah dipilih pada tahapan seleksi data. Proses data cleaning meliputi menghilangkan duplikasi data, memeriksa inkonsistensi data dan memperbaiki kesalahan pada data

3. Transformasi Data

Pada tahapan ini data yang akan dilakukan yaitu mengubah data yang telah dipilih sehingga data sesuai untuk proses data mining, misalkan atribut lama studi yang didapatkan yaitu dalam bentuk bulan maka diubah dijadikan dalam satuan semester hal ini dilakukan untuk memudahkan dalam melakukan analisa hasil.

\subsubsection{Data Mining}

Pada tahapan ini terdapat tiga proses yaitu melakukan clustering dengan Fuzzy C-Means (FCM) dan Fuzzy Subtractive (FS), Validasi Cluster, Analisis Cluster. Berikut ini merupakan proses data mining data alumni :

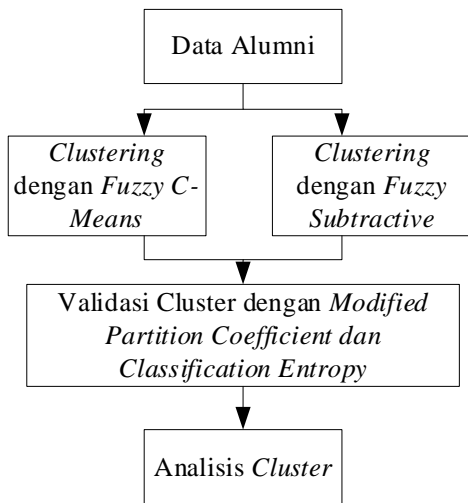

Gambar 5. Proses Data Mining

1. Clustering dengan Fuzzy C-Means dan Fuzzy Subtractive

Setelah data melewati preprosesing maka selanjutnya yaitu melakukan clustering dengan Fuzzy $C$ Mean dan Fuzzy Subtractive.

2. Validasi Cluster 
Tujuan dari validasi cluster untuk menentukan jumlah cluster yang paling optimal dan memvalidasi apakah metode yang diterapkan sesuai dengan data. Proses clustering diuji coba dengan berbagai nilai parameter. Dalam penelian ini menggunakan validasi cluster indeks Modified Partition Coefficient (MPC) (untuk mengukur cluster yang mengalami overlap) dan Classification Entropy (CE) (untuk mengukur tingkat kekaburan/fuzziness dari partisi cluster.

3. Analisis Cluster

Setelah melewati proses data mining dan sudah divalidasi maka tahapan selanjutnya yaitu analisis cluster. Dalam tahapan ini yaitu melakukan analisis terhadap cluster-cluster yang telah terbentuk, hasilnya berupa karakteristik dari profile alumni STIKI Indonesia. Misalkan pada cluster pertama cenderung ditempati oleh IPK diatas 3,6 memiliki lama studi kurang dari 8 semester dan lama pengerjaan tugas akhir selama satu bulan.

\section{Result and Analysis}

Untuk mengetahui tingkat keberhasilan dari penelitian ini, dapat dilihat dari hasil kerja sistem yang telah dibuat. Berikut ini merupakan hasil dan pembahasan yang telah dilakukan.

\subsection{Antar Muka Sistem Clustering}

Pada Gambar 6 dapat dilihat tampilan dari aplikasi analisa clustering data alumni dengan Fuzzy $C$ Means. Aplikasi ini dibuat dengan menggunakan Matlab.

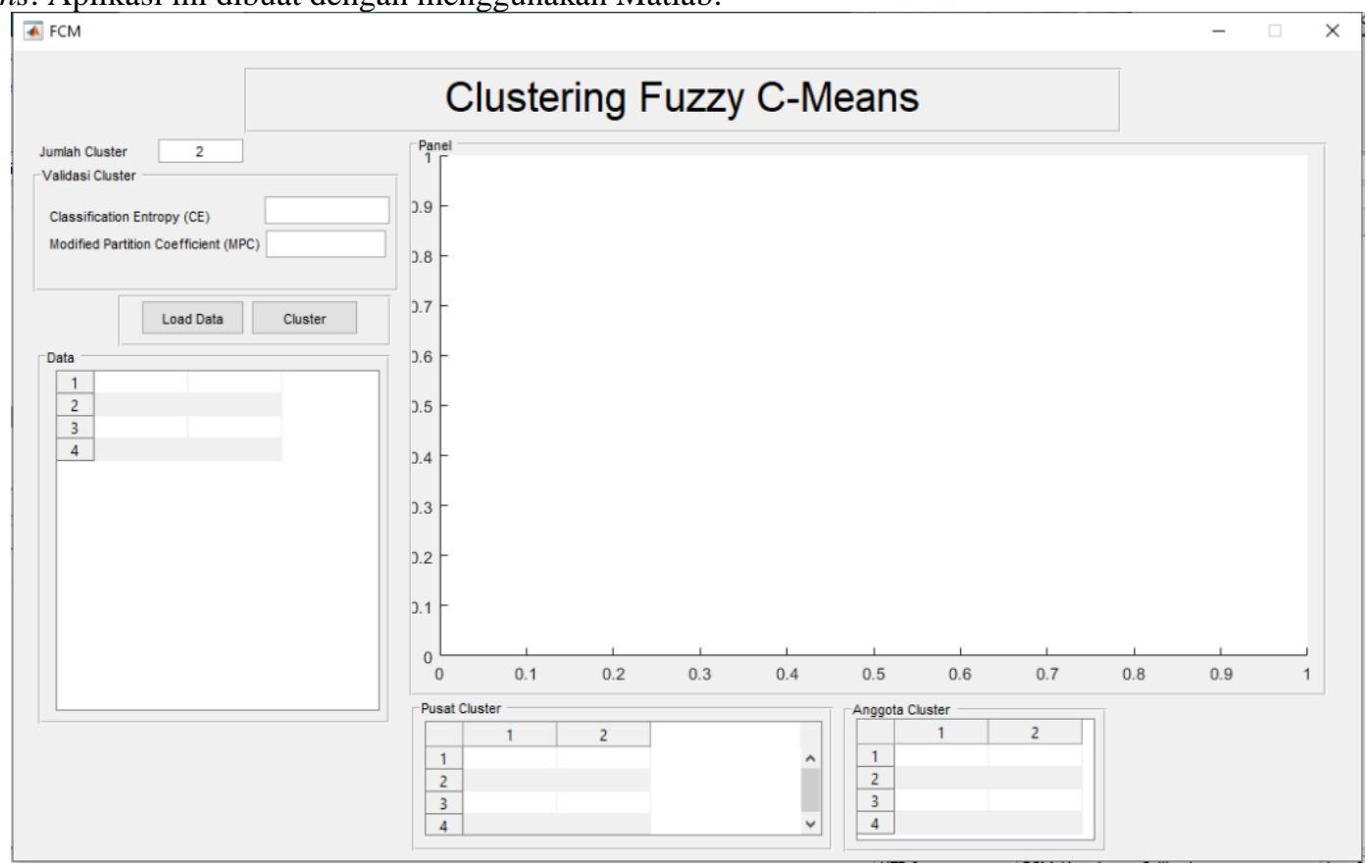

Gambar 6. Antar Muka Sistem Clustering

Pada aplikasi clustering dengan Fuzzy C-Means terdapat beberapa komponen yaitu Inputan jumlah cluster, dimana user bisa menentukan jumlah cluster yang akan terbentuk. Tombol Load data yang berfungsi untuk mengambil data alumni dan menampilkannya ditabel. Tombol Cluster yang berfungsi untuk melakukan clustering data alumni. Output dalam bentuk tabel data, tabel jumlah data dan tabel anggota cluster yang berfungsi untuk menampilkan data alumni, anggota cluster dan pusat cluster. Output dalam bentuk Chart data yang berfungsi untuk menampilkan persebaran data sebelum dan sesudah mengalami proses clustering. Output dalam bentuk textboxt untuk menampilkan nilai MPC dan CE. Subtractive

Pada Gambar 7 dibawah ini dapat dilihat tampilan dari aplikasi clustering data alumni dengan Fuzzy 


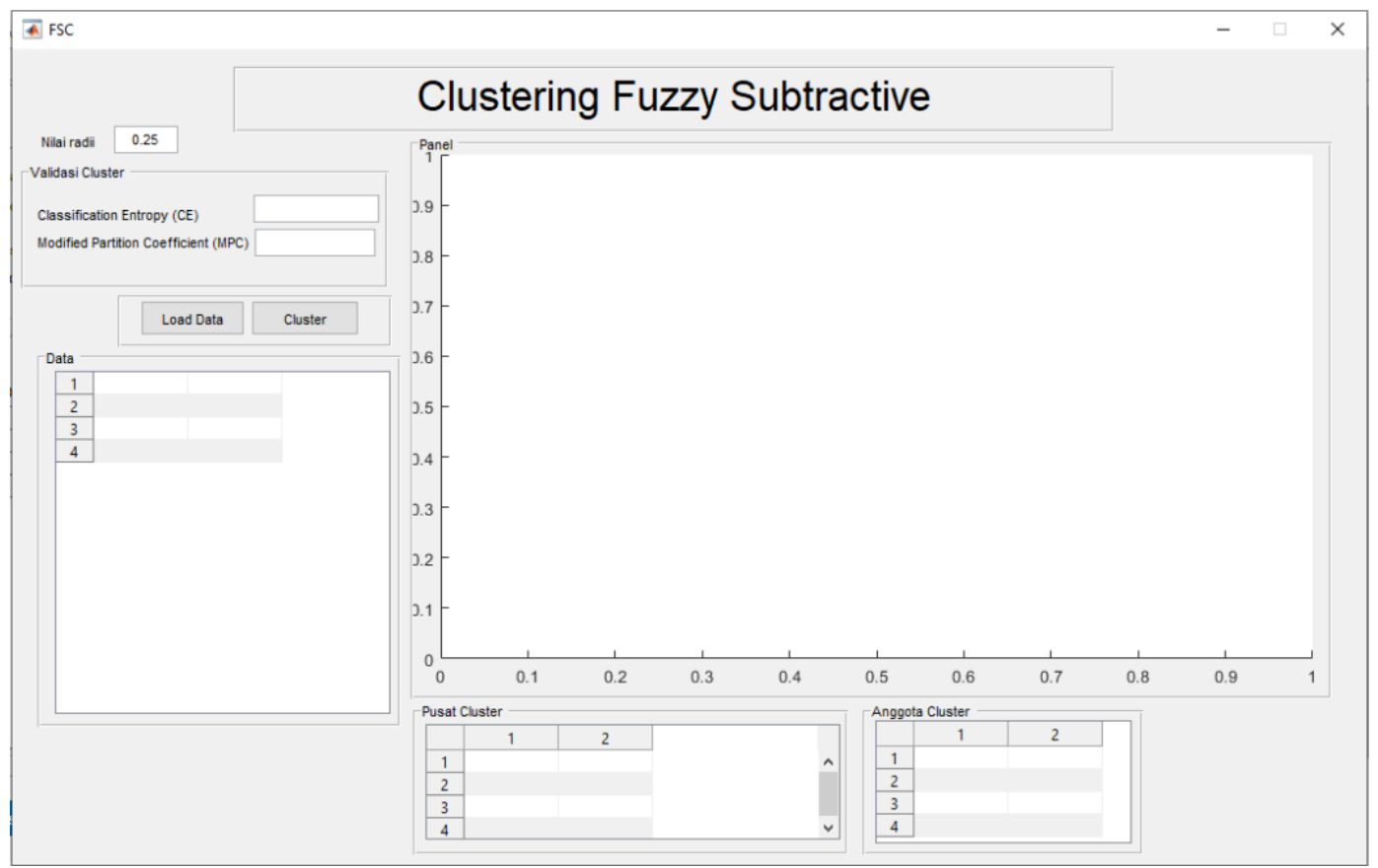

Gambar 7. Tampilan Clustering dengan Fuzzy Substractive

Pada aplikasi clustering dengan Fuzzy Subtractive komponen yang terdapat didalamnya kurang lebih sama dengan clustering Fuzzy C Means, perbedaanya yaitu kalau di clustering dengan Fuzzy C-Means jumlah cluster ditentukan sedangkan kalau di clustering dengan Fuzzy Subtractive jumlah cluster akan otomatis yang menjadi inputan yaitu nilai radii.

\subsection{Clustering Data Alumni dengan Fuzzy C-Means}

Proses clustering data alumni menggukanan algoritma Fuzzy $C$-Means diuji coba dengan berbagai jumlah cluster. Proses clustering dilakukan dengan menetapkan nilai awal sebagai berikut [7]:
1. Jumlah cluster
2. Pangkat
$=2$
3. Maksimum iterasi
$=100$
4. Error terkecil yang diharapkan
$=10^{-5}$
5. Fungsi objektif awal
$=0$
6. Iterasi awal
$=1$

= ditentukan user

Pada Gambar 8 merupakan proses clustering dengan Fuzzy C-Means

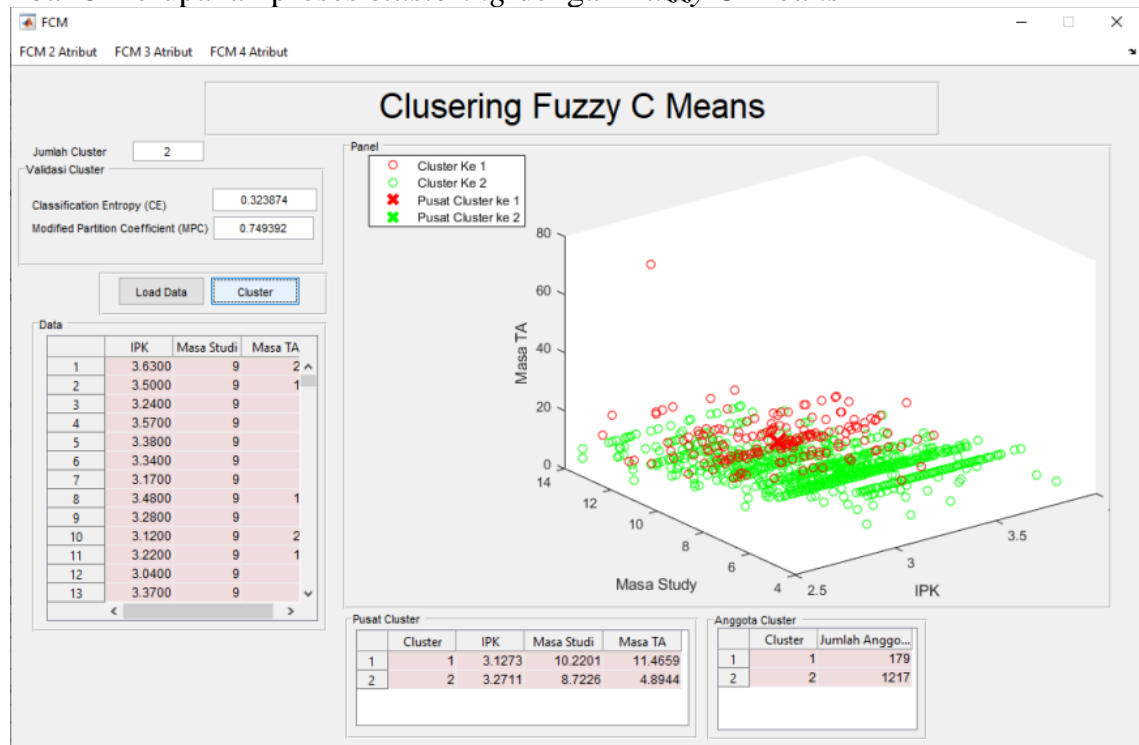

Gambar 8. Clustering dengan Fuzzy C-Means 
Berikut ini merupakan hasil dari proses clustering yang telah dilakukan yaitu:

1. Clustering Alumni Jumlah Cluster 2

Proses clustering dihentikan pada iterasi ke 22 dengan nilai fungsi objectif 8143,613437. Pada Tabel 2 dapat dilihat no cluster, jumlah anggota tiap cluster dan koordinat titik pusat setiap cluster yang terbentuk.

Tabel 2. Koordinat Titik Pusat Cluster (Jumlah Cluster 2)

\begin{tabular}{lllll}
\hline No Cluster & $\begin{array}{l}\text { Jumlah } \\
\text { anggota }\end{array}$ & (IPK) & (Masa Studi) & (Masa TA) \\
\hline $\mathbf{1}$ & 179 & 3,1273 & 10,2201 & 11,4659 \\
\hline $\mathbf{2}$ & 1217 & 3,2711 & 8,7226 & 4,8944 \\
\hline
\end{tabular}

2. Clustering Alumni Jumlah Cluster 3

Proses clustering dihentikan pada iterasi ke 31 dengan nilai fungsi objectif 3363,726197. Pada Tabel 3 dapat dilihat no cluster, jumlah anggota tiap cluster dan koordinat titik pusat setiap cluster yang terbentuk.

Tabel 3. Koordinat Titik Pusat Cluster (Jumlah Cluster 3)

\begin{tabular}{lllll}
\hline No Cluster & $\begin{array}{l}\text { Jumlah } \\
\text { anggota }\end{array}$ & (IPK) & (Masa Studi) & (Masa TA) \\
\hline $\mathbf{1}$ & 168 & 3,1354 & 10,0583 & 11,9801 \\
\hline $\mathbf{2}$ & 394 & 3,0767 & 10,9853 & 4,4481 \\
\hline $\mathbf{3}$ & 834 & 3,3379 & 7,9680 & 5,1642 \\
\hline
\end{tabular}

3. Clustering Alumni Jumlah Cluster 4

Proses clustering dihentikan pada iterasi ke 23 dengan nilai fungsi objectif 4542,811561. Pada Tabel 4 dapat dilihat no cluster, jumlah anggota tiap cluster dan koordinat titik pusat setiap cluster yang terbentuk.

Tabel 4. Koordinat Titik Pusat Cluster (Jumlah Cluster 4)

\begin{tabular}{lllll}
\hline No Cluster & $\begin{array}{l}\text { Jumlah } \\
\text { anggota }\end{array}$ & (IPK) & (Masa Studi) & (Masa TA) \\
\hline $\mathbf{1}$ & 196 & 3,0039 & 12,0157 & 4,5095 \\
\hline $\mathbf{2}$ & 371 & 3,1708 & 9,5580 & 4,9587 \\
\hline $\mathbf{3}$ & 661 & 3,3602 & 7,7876 & 5,1384 \\
\hline $\mathbf{4}$ & 168 & 3,0039 & 12,0157 & 4,5095 \\
\hline
\end{tabular}

4. $\quad$ Clustering Alumni Jumlah Cluster 5

Proses clustering dihentikan pada iterasi ke 26 dengan nilai fungsi objectif 2701.080562. Pada Tabel 5 dapat dilihat no cluster, jumlah anggota tiap cluster dan koordinat titik pusat setiap cluster yang terbentuk.

Tabel 5. Koordinat Titik Pusat Cluster (Jumlah Cluster 5)

\begin{tabular}{lllll}
\hline No Cluster & $\begin{array}{l}\text { Jumlah } \\
\text { anggota }\end{array}$ & (IPK) & (Masa Studi) & (Masa TA) \\
\hline $\mathbf{1}$ & 514 & 3,3617 & 7,8102 & 4,9596 \\
\hline $\mathbf{2}$ & 168 & 3,1359 & 10,0236 & 11,8562 \\
\hline $\mathbf{3}$ & 127 & 2,9799 & 12,3572 & 4,6856 \\
\hline $\mathbf{4}$ & 223 & 3,2937 & 8,2293 & 5,9303 \\
\hline $\mathbf{5}$ & 364 & 3,1386 & 9,9882 & 4,7231 \\
\hline
\end{tabular}

5. Clustering Alumni Jumlah Cluster 6

Proses clustering dihentikan pada iterasi ke 38 dengan nilai fungsi objectif 2170,806330. Pada Tabel 6 dapat dilihat no cluster, jumlah anggota tiap cluster dan koordinat titik pusat setiap cluster yang terbentuk.

Tabel 6. Koordinat Titik Pusat Cluster (Jumlah Cluster 5)

\begin{tabular}{lllll}
\hline No Cluster & $\begin{array}{l}\text { Jumlah } \\
\text { anggota }\end{array}$ & (IPK) & (Masa Studi) & (Masa TA) \\
\hline $\mathbf{1}$ & 214 & 3,1250 & 10,2051 & 4,8680 \\
\hline $\mathbf{2}$ & 514 & 3,3654 & 7,8001 & 4,9775 \\
\hline $\mathbf{3}$ & 127 & 2,9702 & 12,5779 & 4,7937 \\
\hline $\mathbf{4}$ & 159 & 3,1769 & 9,0652 & 4,8631 \\
\hline $\mathbf{5}$ & 214 & 3,2981 & 8,0773 & 5,9811 \\
\hline $\mathbf{6}$ & 168 & 3,1356 & 10,0151 & 11,7736 \\
\hline
\end{tabular}

3.3. Clustering Data Alumni dengan Fuzzy Subtractive 
Proses clustering menggunakan algoritma Fuzzy Subtractive diuji coba dengan berbagai nilai jari-jari atau radii. Proses clustering dilakukan dengan menetapkan nilai awal sebagai berikut[8]:

1. Jari-jari atau radii, biasanya nilai yang terbaik untuk radii berada antara 0,2 dan 0,5.

2. Acccept ratio $=0,5$

3. Reject ratio $=0,15$

4. Squash factor $=1,25$

Gambar 9 di bawah ini merupakan proses clustering dengan Fuzzy Subtractive

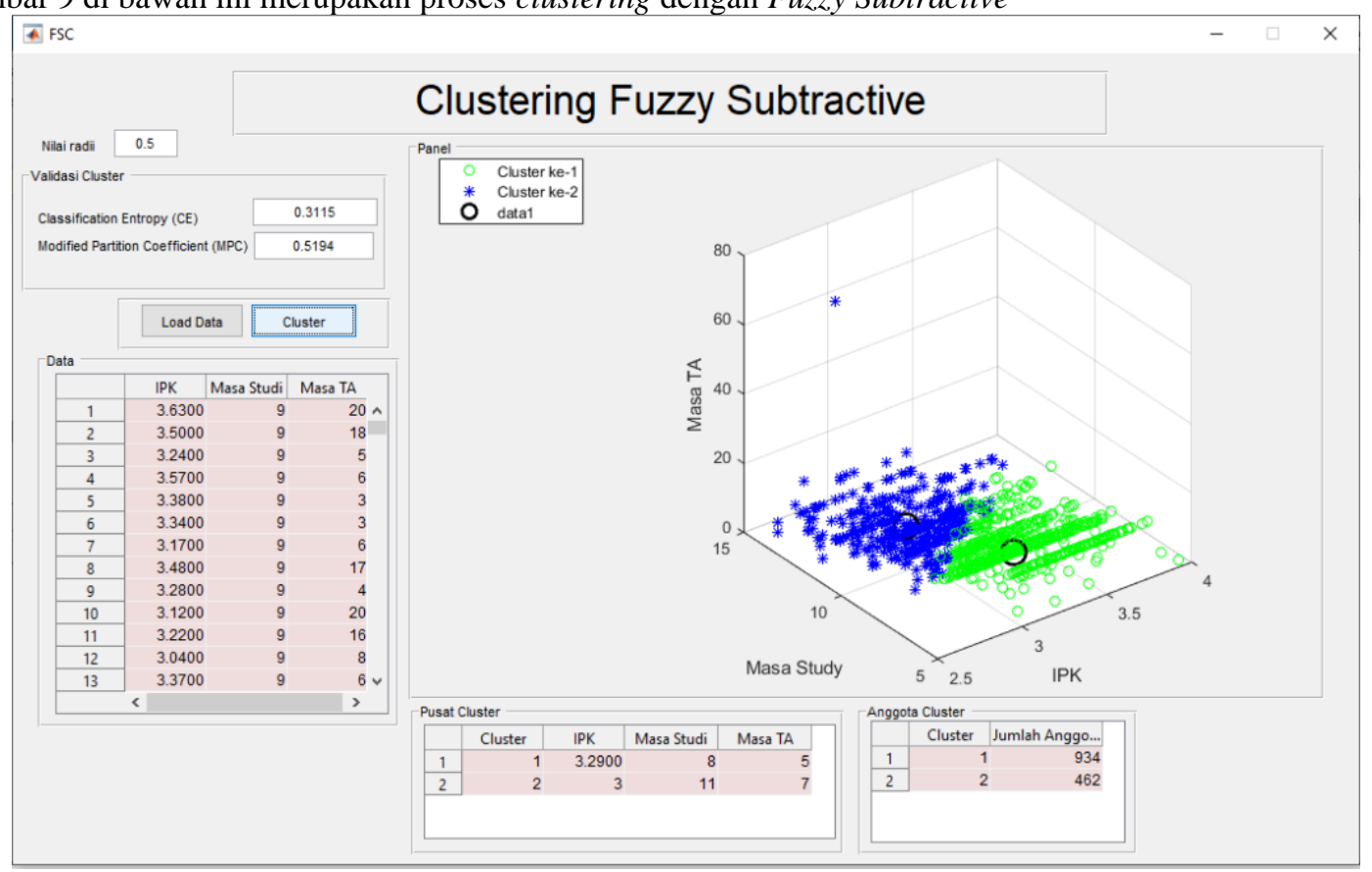

Gambar 9. Clustering dengan Fuzzy Subtractive

Berikut ini merupakan hasil dari proses clustering yang telah dilakukan yaitu:

1. Clustering dengan nilai radii 0,5

Uji coba clustering dengan nilai radii 0,5 menghasilkan 2 cluster. Proses clustering dengan nilai radii $=0,5$ menghasilkan nilai sigma untuk ketiga dimensi data yaitu sigma IPK $=0,2440$, sigma masa studi $=$ 1,5910, sigma masa TA=13,0815. Pada Tabel 7 dapat dilihat no cluster, jumlah anggota tiap cluster dan koordinat titik pusat setiap cluster yang terbentuk.

Tabel 7. Titik Koordinat Pusat Cluster (Radii=0,5)

\begin{tabular}{lllll}
\hline No Cluster & $\begin{array}{l}\text { Jumlah } \\
\text { anggota }\end{array}$ & (IPK) & (Masa Studi) & (Masa TA) \\
\hline $\mathbf{1}$ & 934 & 3,2900 & 8 & 5 \\
\hline $\mathbf{2}$ & 462 & 3 & 11 & 7 \\
\hline
\end{tabular}

2. Clustering dengan nilai radii 0,4

Uji coba clustering dengan nilai radii 0,4 menghasilkan 3 cluster. Proses clustering dengan nilai radii $=0,4$ menghasilkan nilai sigma untuk ketiga dimensi data yaitu sigma IPK =0,1952, sigma masa studi $=1,2728$ sigma masa TA=10,4652. Pada Tabel 8 dapat dilihat no cluster, jumlah anggota tiap cluster dan koordinat titik pusat setiap cluster yang terbentuk.

Tabel 8. Titik Koordinat Pusat Cluster (Radii=0,4)

\begin{tabular}{lllll}
\hline No Cluster & $\begin{array}{l}\text { Jumlah } \\
\text { anggota }\end{array}$ & (IPK) & (Masa Studi) & (Masa TA) \\
\hline $\mathbf{1}$ & 675 & 3,3000 & 8 & 5 \\
\hline $\mathbf{2}$ & 549 & 3,0300 & 10 & 7 \\
\hline $\mathbf{3}$ & 172 & 3,7400 & 7 & 5 \\
\hline
\end{tabular}

3. Clustering dengan nilai radii 0,3

Uji coba clustering dengan nilai radii 0,3 menghasilkan 4 cluster. Proses clustering dengan nilai radii $=0,3$ menghasilkan nilai sigma untuk ketiga dimensi data yaitu sigma IPK $=0.1464$, sigma masa studi $=$ 
0.9546, sigma masa $\mathrm{TA}=7.8489$. Pada Tabel 9 dapat dilihat no cluster, jumlah anggota tiap cluster dan koordinat titik pusat setiap cluster yang terbentuk.

Tabel 9. Titik Koordinat Pusat Cluster (Radii=0,3)

\begin{tabular}{lllll}
\hline No Cluster & $\begin{array}{l}\text { Jumlah } \\
\text { anggota }\end{array}$ & (IPK) & (Masa Studi) & (Masa TA) \\
\hline $\mathbf{1}$ & 565 & 3,3000 & 8 & 5 \\
\hline $\mathbf{2}$ & 391 & 3,0600 & 10 & 6 \\
\hline $\mathbf{3}$ & 267 & 3,6200 & 8 & 5 \\
\hline $\mathbf{4}$ & 173 & 2,8700 & 12 & 5 \\
\hline
\end{tabular}

4. Clustering dengan nilai radii 0,25

Uji coba clustering dengan nilai radii 0,25 menghasilkan 5 cluster. Proses clustering dengan nilai radii $=0,25$ menghasilkan nilai sigma untuk ketiga dimensi data yaitu sigma $\mathrm{IPK}=0,1220$, sigma masa studi $=0,7955$, sigma masa TA $=6,5407$. Pada Tabel 10 dapat dilihat no cluster , jumlah anggota tiap cluster dan koordinat titik pusat setiap cluster yang terbentuk.

Tabel 10. Titik Koordinat Pusat Cluster (Radii=0,25)

\begin{tabular}{lllll}
\hline No Cluster & $\begin{array}{l}\text { Jumlah } \\
\text { anggota }\end{array}$ & (IPK) & (Masa Studi) & (Masa TA) \\
\hline $\mathbf{1}$ & 419 & 3,3000 & 8 & 5 \\
\hline $\mathbf{2}$ & 333 & 3,0900 & 10 & 6 \\
\hline $\mathbf{3}$ & 286 & 3,5900 & 8 & 5 \\
\hline $\mathbf{4}$ & 179 & 3,0300 & 8 & 5 \\
\hline $\mathbf{5}$ & 179 & 2,9000 & 12 & 5 \\
\hline
\end{tabular}

\section{Clustering dengan nilai radii 0,205}

Uji coba clustering dengan nilai radii 0,205 menghasilkan 6 cluster. Proses clustering dengan nilai radii $=0,205$ menghasilkan nilai sigma untuk ketiga dimensi data yaitu sigma IPK $=0,1000$, sigma masa studi $=0,6523$, sigma masa TA $=5,3634$. Pada Tabel 11 dapat dilihat no cluster, jumlah anggota tiap cluster dan koordinat titik pusat setiap cluster yang terbentuk.

Tabel 11. Titik Koordinat Pusat Cluster (Radii=0,205)

\begin{tabular}{lllll}
\hline No Cluster & $\begin{array}{l}\text { Jumlah } \\
\text { anggota }\end{array}$ & (IPK) & (Masa Studi) & (Masa TA) \\
\hline $\mathbf{1}$ & 382 & 3,3100 & 8 & 5 \\
\hline $\mathbf{2}$ & 266 & 3,1000 & 9 & 5 \\
\hline $\mathbf{3}$ & 211 & 3,5600 & 8 & 5 \\
\hline $\mathbf{4}$ & 182 & 3,2400 & 10 & 7 \\
\hline $\mathbf{5}$ & 277 & 2,9600 & 11 & 5 \\
\hline $\mathbf{6}$ & 78 & 3,7500 & 7 & 5 \\
\hline
\end{tabular}

\subsection{Analisis Cluster}

Dari pengujian yang telah dilakukan dengan menggunakan data alumni dari wisuda pertama sampai pada wisuda angkatan ke 10 dengan jumlah data 1396 maka dapat dianalisis beberapa hal. Untuk menentukan jumlah cluster yang memiliki nilai fitness terbaik digunakan indeks pengukuran validitas Modified Partition Coeficient (MPC) dan Classification Entropy (CE). Tabel 12. menunjukkan nilai indeks MPC dan CE untuk setiap jumlah cluster yang diujikan pada algoritma Fuzzy C-Means (FCM) dan Fuzzy Subtractive (FS) Clustering.

Tabel 12. Indeks MPC dan CE pada Algoritma FCM dan FS

\begin{tabular}{lllllll}
\hline Jumlah Cluster & & $\mathbf{2}$ & $\mathbf{3}$ & $\mathbf{4}$ & $\mathbf{5}$ & $\mathbf{6}$ \\
\hline Indeks & FCM & 0,749392 & 0,6453 & 0,565366 & 0,789592 & 0,501937 \\
MPC & FS & 0,5194 & 0,5019 & 0,6014 & 0,7324 & 0,6346 \\
\hline Indeks & FCM & 0,323874 & 0,614129 & 0,896933 & 1,11924 & 1,263 \\
CE & FS & 0,3315 & 0,6829 & 0,9432 & 0,2142 & 0,2832 \\
\hline
\end{tabular}

Nilai indeks MPC untuk masing-masing jumlah cluster pada algoritma Fuzzy C-Means lebih besar dibandingkan Fuzzy Subtractive Clustering. Sedangkan nilai indeks CE untuk masing-masing jumlah cluster pada algoritma Fuzzy C-Means lebih kecil dibandingkan Fuzzy Subtractive Clustering. Dari hasil perbandingan tersebut algoritma Fuzzy C-Means memiliki kinerja yang lebih baik dibandingkan algoritma Fuzzy Subtractive Clustering. 
Berdasarkan Tabel 12 juga dapat dilihat bahwa nilai indeks MPC yang terbesar untuk clustering dengan Fuzzy C-Means dan clustering dengan Fuzzy Subtractive berada pada jumlah cluster $=5$. Untuk nilai indeks CE yang terkecil untuk clustering dengan Fuzzy C-Means dan clustering dengan Fuzzy Subtractive berada pada jumlah cluster $=5$. Sehingga berdasakan indeks CE (nilai terkecil) dan indeks MPC (nilai terbesar), jumlah cluster yang paling optiomal untuk data alumni dengan 3 buah atribut (IPK, masa study dan masa TA) adalah 5 cluster. Karakterisik dari data berdasarkan Tabel 5 yang terdapat pada clustering dengan jumlah cluster 5 dengan metode Fuzzy C-Means yaitu cluster 1 yang jumlah anggotanya 514 orang memiliki rata-rata IPK 3,3617, masa studi rata-rata 7.8102 semester dan masa pengerjaan TA rata-rata 4,9596 bulan. cluster 2 yang jumlah anggotanya 168 orang memiliki rata-rata IPK 3,1359, masa studi rata-rata 10,0236 semester dan masa pengerjaan TA rata-rata 11,8562 bulan. cluster 3 yang jumlah anggotanya 127 orang memiliki rata-rata IPK 2,9799, masa studi rata-rata 12,3572 semester dan masa pengerjaan TA rata-rata 4,6856 bulan. cluster 4 yang jumlah anggotanya 223 orang memiliki rata-rata IPK 3,2937, masa studi rata-rata 8,2293 semester dan masa pengerjaan TA rata-rata 5,9303 bulan. cluster 5 yang jumlah anggotanya 364 orang memiliki IPK ratarata 3,1386, masa studi rata-rata 9,9882 semester dan masa pengerjaan TA rata-rata 4,7231 bulan.

Jadi untuk clustering dengan 3 atribut (IPK, Masa Studi, Masa TA) jumlah cluster yang memiliki nilai fitnes terbaik/jumlah cluster yang paling optimal berdasarkan indeks validitas CE dan MPC yaitu adalah 5 cluster. Cluster yang memiliki karakteristik terbaik adalah cluster ke 1 yang memiliki anggota sebanyak 514 orang $(36,82 \%$ dari total alumni).

\section{Conclusion}

Berdasarkan pengujian dan analisis yang telah dilakukan maka dapa ditarik simpulan sebagai berikut:

1. Hasil pengukuran validitas cluster menggunakan indeks Modified Partition Coefficient (MPC) dan Classification Entropy (CE), algoritma Fuzzy C-Means Clustering memiliki tingkat validitas lebih tinggi dibandingkan algoritma Fuzzy Subtractive Clustering sehingga dapat dikatakan bahwa algoritma Fuzzy CMeans melakukan proses cluster lebih baik dibandingkan dengan metode Fuzzy Subtractive dalam melakukan clustering data alumni. Jumlah cluster yang terbaik berdasarkan indeks MPC dan CE adalah 5.

2. Untuk clustering dengan 3 atribut (IPK, Masa Studi, Masa TA) jumlah cluster yang memiliki nilai fitnes terbaik/jumlah cluster yang paling optimal berdasarkan indeks validitas CE dan MPC yaitu adalah 5 cluster. Cluster yang memiliki karakteristik terbaik adalah cluster ke 1 yang dengan karakteristik memiliki rata-rata IPK 3,3617, masa studi rata-rata 7,8102 semester dan masa pengerjaan TA rata-rata 4,9596 bulan memiliki anggota sebanyak 514 orang (36,82\% dari total 1396 alumni).

\section{References}

[1]. Supartha, I Kadek Dwi Gandika; Sudarma, Made; Wiharta, Dewa Made. Sistem Informasi Geografis Pemetaan Persebaran Alumni dengan Analisa Clustering. Majalah Ilmiah Teknologi Elektro, [S.l.], v. 17, n. 3, p. 377-384, dec. 2018. ISSN 2503-2372.

[2]. Iskandar, Adi Panca Saputra; Supartha I Kadek Dwi Gandika. Sistem Informasi Geografis Sebaran Alumni Pada STMIK STIKOM Indoensia. J-COSINE, Vol. 3, No.2 Desember 2019

[3]. Tan, P.N., Steinbach, M. \& Kumar, V. 2006. Introduction to Data Mining. Pearson Education, Inc.

[4]. Jain, A. K., Murthy, M. N. \& Flynn, P. J. (1999). Data Clustering: A Review. ACM Computing Surveys, Vol. 31, No. 3.

[5]. Hammouda, K., Prof. Karaay, F. 2000. A Comparative Study of Data Clustering Techniques. University of Waterloo, Ontario, Canada.

[6]. Tan, P.N., Steinbach, M. \& Kumar, V. 2006. Introduction to Data Mining. Pearson Education, Inc.

[7]. Yan, J., Power, J., 1994. Using Fuzzy Logic (Toward Intelligent System). Prentice Hall, New York.

[8]. Gelley, N., Jang, R. 2000. Fuzzy Logic Toolbox. Mathwork, Inc., USA. 